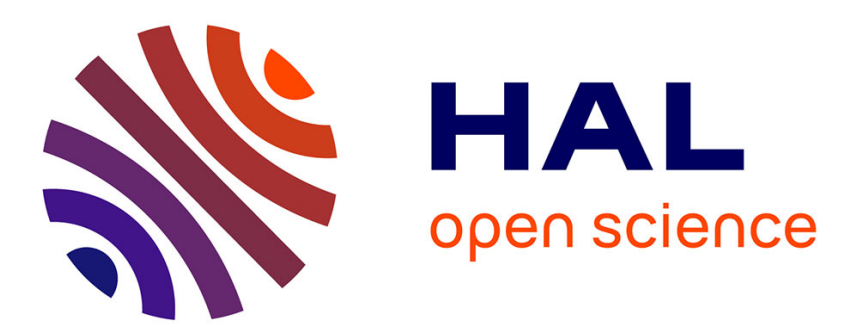

\title{
Production of clay ceramics using agricultural wastes: Study of properties, energy savings and environmental indicators
}

\author{
R. Sani, Ange Nzihou
}

\section{- To cite this version:}

R. Sani, Ange Nzihou. Production of clay ceramics using agricultural wastes: Study of properties, energy savings and environmental indicators. Applied Clay Science, 2017, 146, p.106-114. 10.1016/j.clay.2017.05.032 . hal-01581810

\section{HAL Id: hal-01581810 https://imt-mines-albi.hal.science/hal-01581810}

Submitted on 31 Jan 2019

HAL is a multi-disciplinary open access archive for the deposit and dissemination of scientific research documents, whether they are published or not. The documents may come from teaching and research institutions in France or abroad, or from public or private research centers.
L'archive ouverte pluridisciplinaire HAL, est destinée au dépôt et à la diffusion de documents scientifiques de niveau recherche, publiés ou non, émanant des établissements d'enseignement et de recherche français ou étrangers, des laboratoires publics ou privés. 


\title{
Production of clay ceramics using agricultural wastes: Study of properties, energy savings and environmental indicators
}

\author{
R. Sani*, A. Nzihou \\ Université de Toulouse, Mines Albi, CNRS, Centre RAPSODEE, Campus Jarlard, Route de Teillet, F-81013 Albi Cedex 09, France
}

\section{A B S T R A C T}

In this study, agro-wastes were used as additive raw materials for the production of fired clay ceramics. The objectives of this study are to evaluate the impact of adding agro-wastes into clay body on the thermal and mechanical properties of ceramic materials, to determine the net energy consumption and to determine gas emissions during firing process. The clay and agro-wastes were characterized by chemical elemental analysis, thermogravimetric and differential thermal analysis (TGA-DTA). The fired clay ceramics were produced with clay and optimal proportions of wheat straw (WS) and olive core flour (OCF). The thermal and mechanical properties were evaluated by measuring thermal conductivity with hot-disk method and bending test respectively. The results showed that for clay incorporated OCF $(4,8 \mathrm{wt} \%)$ and $\mathrm{WS}(3,7 \mathrm{wt} \%)$, thermal conductivity was decreased by 16 to $30 \%$. However, the mechanical strength of the same samples has slightly decreased respectively. TGA-DTA provided an approach to estimate the heat required or released for both clay and agro-wastes thermal decomposition. The addition of agro-wastes into the clay body showed that energy consumption of fired clay ceramics production decreased to above $36 \%$ for clay incorporated $4 \mathrm{wt} \%$ OCF (C-4wt $\% \mathrm{OCF}$ ). The energy saving during the firing process was a tangible outcome. In order to determine the impact of the agro-wastes addition, the environmental indicators were discussed for the clay incorporated WS and OCF respectively. Total gas yield released were measured by Micro-GC after the combustion of clay incorporated OCF and WS in fixed bed reactor respectively. The analysis of gas emissions are related to the combustion of organic and inorganic compounds of agro-wastes and clay body, respectively. The $\mathrm{CO}_{2}$ emissions coming from the combustion of agro-wastes reached up to $4.38 \%$ for C- 8 wt $\%$ OCF. However, the $\mathrm{CO}_{2}$ emissions associated with decarbonatation of clay body decreased. Adding agro-wastes into the clay body results to improving thermal properties without negative impact on the mechanical properties of ceramic materials, also to a significant energy saving and decreasing of the inorganic $\mathrm{CO}_{2}$ emissions related to the decarbonatation of clay body. The relevance of this work, pointed out in the data presented in regards to the state-of-the art is that the paper is focused on fired clay ceramic properties, on energy savings and on the evaluation of environmental indicators in the laboratory scale.

\section{Keywords:}

Ceramics

Agro-wastes

Thermal conductivity

Mechanical strength

Energy savings

Environmental indicators

\section{Introduction}

Several scientific research have been carried out on the study of the physical and chemical properties of ceramic materials in their production process in order to optimize their final properties (Cultrone et al., 2004a; Vassilev et al., 2013). Number of studies have investigated the use of industrial and organic wastes to produce ceramic material such as bricks (Demir, 2006; Muñoz Velasco et al., 2014; Raut et al., 2011) including sewage sludge, fly ash and organic residues from agroindustries paper or wood. (Demir, 2006) mixed Processed Waste Tea (PWT) with clay body to improve the insulation ability of bricks by generating porosity. This author noticed also that the compressive strength of ceramic materials increased significantly by adding PWT into the clay body. Also, the microstructure of clay and additives, granulometry and the contents of additives were studied to develop the optimal formulations (Faria et al., 2012; Madurwar et al., 2013).

The consumption of earth-based materials such as clay and sand in the production of bricks resulted in resources depletion, environmental degradation and energy consumption. The biomass as an agricultural product has been used as an energy source to lower energy consumption in brick manufacturing process. The application of these agrowastes for the production of ceramic materials is consistent with the concept of improving the efficiency of management and the environmental impact of wastes (Zabalza Bribián et al., 2011). From a

\footnotetext{
Corresponding author

E-mail address: rababe.sani@mines-albi.fr (R. Sani).
} 
microstructural point of view, the addition of organic residues in clay raw materials induces the pore formation. This investigation influences the final properties of fired clay bricks (Freyburg and Schwarz, 2007; Gualtieri et al., 2010). On the one hand the thermal properties were determined by the agro-wastes insulating behavior and on the other hand the mechanical properties are strongly related to the particular morphology of the pores induced in the fired clay bricks (Bories et al., 2014; Sutcu and Akkurt, 2009).

It is well known that material production industries have been recognized as one of the largest fuel consuming sectors of the economy (Koroneos and Dompros, 2007). The energy cost for such large scale production in the ceramic industry has become a critical issue. The agro-wastes incorporation within clay bricks can contribute to energy savings by reducing the energy requirements of the brick firing industrial scale. Few studies were focused on the effect of the amount and the type of agro-wastes incorporated in fired clay bricks, their behavior during combustion in the firing stage and their impact on the energy consumption of the process. Very little researches pay attention to develop an eco-friendly fired bricks in an economical and environmental stand point (González et al., 2011; Quijorna et al., 2012).

The relevance of this work, in regards to the state-of-the art is that the paper is focused on mechanical and thermal properties together with the investigation of energy savings and environmental indicators of materials in the laboratory scale. The thermal and mechanical properties were obtained by standards methods and the energy consumption occurring in the firing stage and their relationships with the chemical structure of biomass components (cellulose, hemicellulose and lignin) were discussed. In the other case, the releasing behaviors of $\mathrm{CO}_{2}$ and total gas emissions were measured using Micro-GC. Regarding $\mathrm{CO}_{2}$, we have been able to discriminate the fate released from inorganic source such as $\mathrm{CaCO}_{3}$ with the one released from organic source from agro-wastes.

\section{Materials and methods}

\subsection{Characterization of brick raw materials}

The agro-wastes release heat during combustion which depends on its composition. Elemental analysis was carried out using CHNS of respectively olive core flour (OCF) presenting spherical particles of $50 \mu \mathrm{m}$ and wheat straw (WS) presenting a lamellar structure with $1 \mathrm{~mm}$ particle sizes. In fact, a flash combustion of samples followed by chromatographic separation provides the amount of carbon, hydrogen, nitrogen and sulfur respectively.

The high heating value (HHV) of agro-wastes was determined by using a calorimeter bomb C500 CONTROL IKA. The combustion process was realized under pressure of 30 bars of oxygen at $25^{\circ} \mathrm{C}$ using $1 \mathrm{~g}$ of samples. According to the standard NF EN 14918 (NF EN 14908 , 2010), the calorimeter bomb used had an internal volume of $250 \mathrm{~mL}$. In order to avoid any acid gas released during combustion, $10 \mathrm{~mL}$ of $0.05 \mathrm{~mol} / \mathrm{L} \mathrm{Na}_{2} \mathrm{CO}_{3}$ (aq) was added to the combustion bomb. The HHV was then determined at reference temperature of $25^{\circ} \mathrm{C}$.

The raw clay used in this study was supplied by TERREAL (Castelnaudary, France). The chemical analysis of the raw clay was considered. The final properties of fired bricks are strongly influenced by the chemical and mineralogical compositions of raw clay. The chemical composition was determined by Inductively Coupled Plasma - Optical Emission Spectrometry (ICP-OES). The clay samples were immersed in a hydrofluoric acid solution (48 wt\%) and perchloric acid (64 wt \%), in respective proportions of 75 and $25 \% . v o l$, then heated up to a temperature of $80{ }^{\circ} \mathrm{C}$ for $30 \mathrm{~min}$.

The qualitative determination of major crystalline mineralogical phases present in the clay was achieved by X-ray diffractometer using the PanAlytical X'Pert Philips ( $45 \mathrm{~mA}, 40 \mathrm{kV}$ ). The determination of crystalline phases of clay was realized at $600{ }^{\circ} \mathrm{C}, 700{ }^{\circ} \mathrm{C}, 800{ }^{\circ} \mathrm{C}$ and $900{ }^{\circ} \mathrm{C}$ using a copper anticathode $(\lambda$ copper $=1,54 \AA$ ) for $2 \theta$ angles ranging from 4 to $75^{\circ}$ in steps of $0.017^{\circ}$ and every $29 \mathrm{~s}$. The patterns were exploited by using software X'Pert HighScore based on ICDD database (International Centre for Diffraction Data) to identify the peaks corresponding to each component. The main databases used were PDF2 (Predicted Powder Diffraction Database) and COD (Crystallography Open Database). The XRD analysis was completed by a semi-quantitative study using a calibration method namely Reference Intensity Ratio (RIR) method. The PDF2 and COD database were used also to quantify the crystalline phases.

To understand the decomposition of OCF, WS and raw clay respectively, the thermal behavior was determined by thermogravimetric and differential thermal analyses (TGA-DTA) using a TG-ATD 92 by SETARAM equipment under air atmosphere. Samples of about $100-200 \mathrm{mg}$ were placed in a platinum crucible, and heated up at $5{ }^{\circ} \mathrm{C} / \mathrm{min}$ from the room temperature to $1000^{\circ} \mathrm{C}$. The energy of transformation associated with the decomposition of OCF, WS and clay body was determined respectively by the enthalpies estimation method.

\subsection{Samples preparation}

Olive core flour (OCF) and wheat straw (WS) presenting respectively particles of $50 \mu \mathrm{m}$ and $1 \mathrm{~mm}$, were incorporated in clay body of $100 \mu \mathrm{m}$. The raw clay, sand, WS and OCF were then mixed together by a laboratory-type blender. A quantity of water (up to $22 \mathrm{wt} \%$ depending on the formula) was added to the mixtures Clay/OCF or WS to obtain 7.5-8.0 bars pressure of extrusion. Four formulations were prepared using $3,7 \mathrm{wt} \%$ of $\mathrm{WS}$ and $4,8 \mathrm{wt} \%$ of OCF respectively.

The samples were then extruded and shaped as molds of $180 \mathrm{~mm} \times 80 \mathrm{~mm} \times 18 \mathrm{~mm}$. In order to avoid some defaults such as cracks or problems of efflorescence, the drying process were carried out at a high relative humidity (RH) of $25 \%$ at $105{ }^{\circ} \mathrm{C}$ for $24 \mathrm{~h}$ and terminated with a relative humidity of $5 \%$. The shaped samples without waste $(20 \mathrm{wt} \%$ sand $+80 \mathrm{wt} \%$ raw clay) namely clay body were designed as $\mathrm{C}$ and for the mixtures $\mathrm{C}-\mathrm{X}$ wt $\% \mathrm{OCF}$ or $\mathrm{C}-\mathrm{X} \mathrm{wt} \% \mathrm{WS}$, where $\mathrm{X}$ indicates the amount in the clay body.

\subsection{Characterization of the bricks}

A thermal property, such as the thermal conductivity $(\lambda)$ was measured by hot-disk method with TPS 2500 apparatus. The samples of bricks were cut from a single green body extruded to the dimensions of $30 \mathrm{~mm} \times 30 \mathrm{~mm} \times 5 \mathrm{~mm}$. The measurements were done after a firing process at $920{ }^{\circ} \mathrm{C}$ with a constant heating rate of $5{ }^{\circ} \mathrm{C} / \mathrm{min}$. For each fired sample, the parallel faces were polished to have a performant contact with the Transient plane source (TPS) sensor.

The bending test was performed to investigate the load bearing capacity of fired clay brick using agro-wastes. The extruded samples were cut to the dimensions of $60 \mathrm{~mm} \times 15 \mathrm{~mm} \times 5 \mathrm{~mm}$. The samples were heated up to $920^{\circ} \mathrm{C}$ (final kiln temperature) with a constant heating rate of $5^{\circ} \mathrm{C} / \mathrm{min}$ and then cooled at room temperature respectively. A three point bending test was performed on fired samples using the mechanical test machine INSTRON $500 \mathrm{~N}$ with a constant rate of $1 \mathrm{~mm} / \mathrm{min}$ until the failure of samples. The fired-bending stress was obtained with the Eq. ((1):

$\sigma=(3 \cdot \mathrm{Fmax} \cdot \mathrm{L}) /\left(2 \cdot \mathrm{e}^{\wedge} 2 \cdot 1\right)$

With $\mathrm{F}_{\max }$ is the force, $\mathrm{L}$ is the loading span, 1 is the breadth and $\mathrm{e}$ is the height of the samples.

The thermal behavior was determined by thermogravimetric and differential thermal analyses (TGA-DTA) using a SETARAM equipment under air atmosphere. Samples of about $100-200 \mathrm{mg}$ were placed in a platinum crucible, and heated up to $1000{ }^{\circ} \mathrm{C}$ with a heating rate of $5{ }^{\circ} \mathrm{C} /$ min.

The released gas from fired samples in the fixed bed reactor named Carbolite was measured using Micro-GC. On the one hand the gas emissions related to decomposition of WS and OCF were measured 
Table 1

Physico-chemical analysis of the agro-wastes (OCF and WS).

\begin{tabular}{llllr}
\hline Sample & wt\%C & wt\%H & wt\%N & HHV $(\mathrm{J} / \mathrm{g})$ \\
\hline WS & $44.4 \pm 0.11$ & $5.6 \pm 0.07$ & $0.4 \pm 0.07$ & $0.00 \pm 0.01$ \\
OCF & $49.8 \pm 0.09$ & $6.0 \pm 0.13$ & $0.3 \pm 0.01$ & $17,859 \pm 24$ \\
\hline
\end{tabular}

between $200{ }^{\circ} \mathrm{C}$ and $500{ }^{\circ} \mathrm{C}$, on the other hand between $600{ }^{\circ} \mathrm{C}$ and $830^{\circ} \mathrm{C}$ the gas related to decarbonatation of clay body were also measured. One of the main objectives of this work is to quantify the $\mathrm{CO}_{2}$ emission related to the raw materials of clay bricks. The $\mathrm{CO}_{2}$ related to fuel or other source of energy in the firing stage was not taken into account in this study.

\section{Results and discussion}

\subsection{Agro-wastes characterization}

OCF has a highest carbon content which in combustion releases a significant amount of the heat (Table 1). The thermal behavior is determined by means of thermogravimetric analysis which will be detailed below. The high heating value (HHV) was used later to quantify the lower heating value (LHV) based on the results of CHNS analysis and the value of the latent heat.

The chemical composition and nature of the biomass polymers differ significantly with biomass types. Biomass is composed with 3 polymers named hemicellulose, cellulose and lignin. The results of the chemical composition of WS and OCF have been combined in the Table 2 (dry matter content, fiber, proteins, lipids and ash) were made in previous works (Bories et al., 2015).

Fig. 1 represents the TGA-DTA curves of OCF. First mass loss of $5 \mathrm{wt}$ $\%$ attributed to the dehydration of OCF (A) was observed before $200{ }^{\circ} \mathrm{C}$. The combustion of OCF started between $200^{\circ} \mathrm{C}$ and $450{ }^{\circ} \mathrm{C}$ (B). The total mass loss was at least $94 \mathrm{wt} \%$ which proved that only a small content of ash was produced by combustion. The DTA curve of OCF (Fig. 1) shows that between $30^{\circ} \mathrm{C}$ and $200{ }^{\circ} \mathrm{C}(\mathrm{A})$, the dehydration of OCF samples was indicated by the endothermic peak centered at $90^{\circ} \mathrm{C}$. Then, the decomposition of the hemicellulose started at $200{ }^{\circ} \mathrm{C}$ and continued up to about $325^{\circ} \mathrm{C}$ (B). This decomposition superimposed with the one associated with cellulose in a temperature range between $240^{\circ} \mathrm{C}$ and $375^{\circ} \mathrm{C}$ (B), which is the second component thermally less stable degradation occurred in a temperature range of $240{ }^{\circ} \mathrm{C}$ and $350{ }^{\circ} \mathrm{C}$. Finally, the exothermic peak between $350^{\circ} \mathrm{C}$ and $450{ }^{\circ} \mathrm{C}$ (B) indicated the decomposition of lignin. Such a behavior is commonly observed in the literature (Fateh et al., 2013; López-González et al., 2013; Yang et al., 2007a). After this zone (B), OCF is totally decomposed.

The TGA-DTA curves of WS as shown in Fig. 2 present similar modifications as OCF with larger deviations. The curves demonstrated that WS was decomposed totally between $220^{\circ} \mathrm{C}$ and $500{ }^{\circ} \mathrm{C}$. The biomass as seen in the literature (Diblasi, 2008; Pasangulapati et al., 2012; Stenseng et al., 2001) consists of three major polymers: hemicellulose, cellulose and lignin were decomposed one after the other or even a parallel depending on the chemical composition of each type of biomass and its moisture content. These polymer chains are linked by relatively weak bonds ( 380 to $420 \mathrm{~kJ} / \mathrm{mol}$ ) that break before $500{ }^{\circ} \mathrm{C}$. The release of the volatile compounds held from $220^{\circ} \mathrm{C}$ to $500{ }^{\circ} \mathrm{C}(\mathrm{B})$

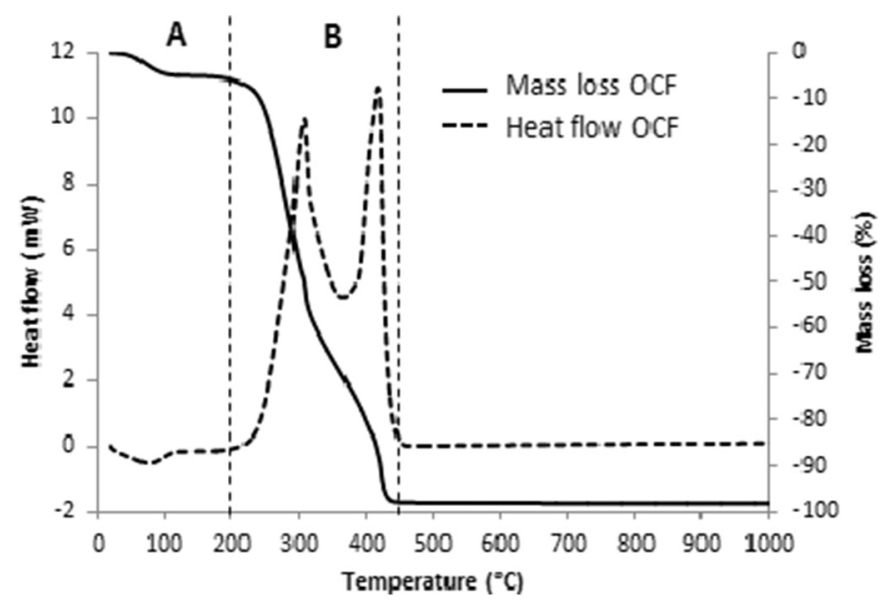

Fig. 1. TGA-DTA of OCF.

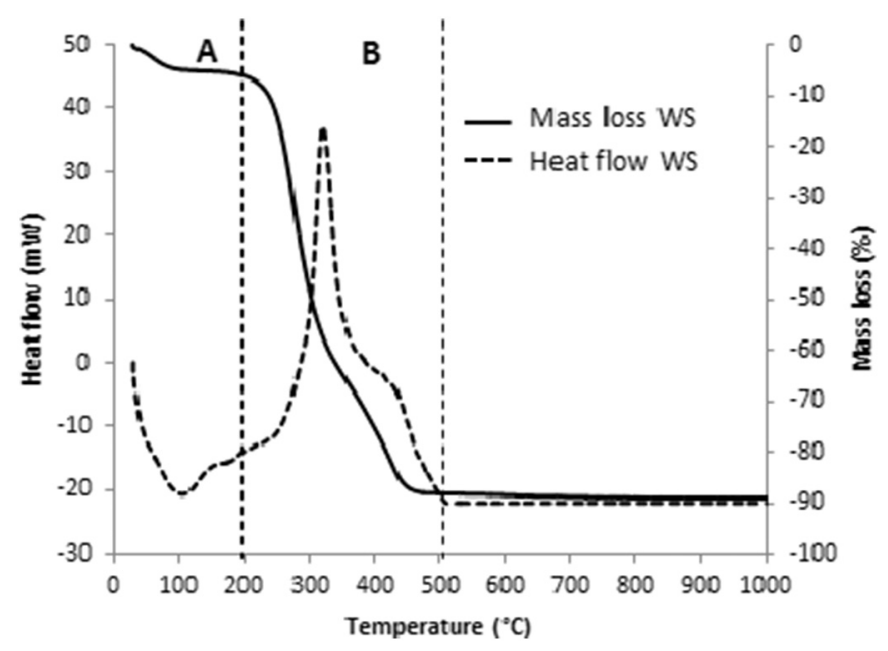

Fig. 2. TGA-DTA of WS.

and the chemical composition of the biomass can play a role on the amount of ash produced by combustion, especially wheat straw having a high content of alkali metals ( $\mathrm{Na}$ and $\mathrm{K}$ ). Beyond $500{ }^{\circ} \mathrm{C}$ the WS is totally decomposed.

These peaks represent energy release from biomass degradation under operating conditions similar to the manufacturing process used at industrial scale on our study. So, the thermogravimetric analysis has been used to evaluate energy balances in the combustion process.

Among the three major components of biomass, hemicellulose is the most sensitive to heat so it decomposed in a temperature range between $200{ }^{\circ} \mathrm{C}$ and $325^{\circ} \mathrm{C}(\mathrm{B})$. This decomposition occurred in two stages. The polymer decomposed into fragments and the conversion of monomer

Table 2

The chemical composition of WS and OCF (Bories et al., 2015).

\begin{tabular}{llllrrr}
\hline Biomass & wt $\%$ cellulose & wt $\%$ hemi-cellulose & wt $\%$ lignin & wt\% dry matter & wt $\%$ proteins & wt $\%$ lipids \\
\hline WS & $42.1 \pm 1.0$ & $11.8 \pm 0.7$ & $28.9 \pm 0.2$ & $90.8 \pm 0.0$ & $2.1 \pm 0.2$ & $4.5 \pm 0.7$ \\
OCF & $36.8 \pm 0.1$ & $25.6 \pm 0.1$ & $31.2 \pm 0.2$ & $94.6 \pm 0.0$ & $1.2 \pm 0.0$ & $3.5 \pm 0.4$ \\
\hline
\end{tabular}


units which are then decomposed into volatile products (Fateh et al., 2013; Lide, 2005; Shen and Gu, 2009). In comparison with the cellulose, hemicellulose produced more gas, tars and char. The Xylose groups were decomposed under the conditions of pyrolysis to produce acetic acid and furfural. Progressively, the diffusion of oxygen increased within the biomass. Then, the furan produced from the pyrolysis furfural itself decomposed to give acetic acid and formaldehyde. The release of gas consisted mainly of $\mathrm{CO}_{2}, \mathrm{H}_{2} \mathrm{O}$ and saturated or unsaturated hydrocarbons $\mathrm{C}_{\mathrm{x}} \mathrm{H}_{\mathrm{y}}$.

It is possible to quantify the energy of transformation associated with the decomposition of the hemicellulose taken as $\mathrm{C}_{5} \mathrm{H}_{8} \mathrm{O}_{4}$ using enthalpies estimation method (Lide, 2005), for reactions (2), (3) and (4):

$$
\begin{aligned}
& \underset{\text { Hemicellulose }}{\mathrm{C}_{5} \mathrm{H}_{8} \mathrm{O}_{4}} \rightarrow \underset{\text { Furfural }}{\mathrm{C}_{5} \mathrm{H}_{4} \mathrm{O}_{2}}+2 \mathrm{H}_{2} \mathrm{O} \Delta \mathrm{H}_{7}=+2.46 \mathrm{~kJ} / \mathrm{g} \\
& \underset{\text { Furfural }}{\mathrm{C}_{5} \mathrm{H}_{4} \mathrm{O}_{2}} \rightarrow \underset{\text { Furanne }}{\mathrm{C}_{4} \mathrm{H}_{4} \mathrm{O}}+\mathrm{CO} \Delta \mathrm{H}_{8}=+0.06 \mathrm{~kJ} / \mathrm{g} \\
& \underset{\text { Furanne }}{\mathrm{C}_{4} \mathrm{H}_{4} \mathrm{O}}+2.5 \mathrm{O}_{2} \rightarrow \underset{\text { Acetic acid }}{\mathrm{C}_{2} \mathrm{H}_{4} \mathrm{O}_{2}}+2 \mathrm{CO}_{2} \Delta \mathrm{H}_{9}=-17.42 \mathrm{~kJ} / \mathrm{g}
\end{aligned}
$$

The decomposition of hemicellulose is an exothermic reaction, generated heat energy between $200{ }^{\circ} \mathrm{C}$ and $325^{\circ} \mathrm{C}$.

$$
\begin{aligned}
\Delta \mathrm{H}_{\text {hem }} & =(2.46+0.06-17.42) \mathrm{kJ} / \mathrm{g} \\
\Delta \mathrm{H}_{\text {hem }} & =-14.9 \mathrm{~kJ} / \mathrm{g}
\end{aligned}
$$

The reaction of decomposition of cellulose has been studied by Shafizadeh among other studies (Yang et al., 2007). Firstly, at temperatures below $300{ }^{\circ} \mathrm{C}$, a formation of char and an embrittlement of the material were observed. The gaseous products obtained were formed from carbon oxides (particularly $\mathrm{CO}$ ) and water. The main constituent of tar is levoglucosan which was vaporized and decomposed to form water, formic acid, acetic acid. Pyrolysis and combustion of the cellulose can be summarized schematically by the following three reactions (5), (6) and (7):

$$
\begin{aligned}
& \underset{\text { Cellulose }}{\mathrm{C}_{6} \mathrm{H}_{12} \mathrm{O}_{6}} \rightarrow \underset{\text { Levoglucosan }}{\mathrm{C}_{6} \mathrm{H}_{10} \mathrm{O}_{5}}+\mathrm{H}_{2} \mathrm{O} \Delta \mathrm{H}_{10}=-3.73 \mathrm{~kJ} / \mathrm{g} \\
& \underset{\text { Levoglucosan }}{\mathrm{C}_{6} \mathrm{H}_{10} \mathrm{O}_{5}}+4 \mathrm{O}_{2} \rightarrow \underset{\text { Acetic acid }}{\mathrm{C}_{2} \mathrm{H}_{4} \mathrm{O}_{2}}+4 \mathrm{CO}_{2}+3 \mathrm{H}_{2} \mathrm{O} \Delta \mathrm{H}_{11}=-16.05 \mathrm{~kJ} / \mathrm{g}
\end{aligned}
$$

$$
\underset{\text { Acetic acid }}{\mathrm{C}_{2} \mathrm{H}_{4} \mathrm{O}_{2}}+1.5 \mathrm{O}_{2} \rightarrow \underset{\text { Formic acid }}{\mathrm{CH}_{2} \mathrm{O}_{2}}+\mathrm{CO}_{2}+\mathrm{H}_{2} \mathrm{O} \Delta \mathrm{H}_{12}=-0.96 \mathrm{~kJ} / \mathrm{g}
$$

$\Delta \mathrm{H}_{\text {cel }}=(-3.73-16.05-0.96) \mathrm{kJ} / \mathrm{g}$

$\Delta \mathrm{H}_{\text {cel }}=-20.74 \mathrm{~kJ} / \mathrm{g}$

The decomposition of cellulose is an exothermic reaction and generated heat between $240{ }^{\circ} \mathrm{C}$ and $375{ }^{\circ} \mathrm{C}$.

The thermal degradation of lignin produces aromatic compounds and large amounts of char. This reflects the complexity of the lignin macromolecules where a large number of aromatic rings are linked by furans cycles or ether linkages. The first step of decomposition of lignin was observed by breaking fragile ether layers $(\mathrm{C}-\mathrm{O})$ in aromatic fragments according to the reaction (8). At higher temperatures ( $>500{ }^{\circ} \mathrm{C}$ ), lignin is largely responsible of the char formation (55 wt $\%)$ and a large part of the energy transformation with a temperature increase (reaction 9).

$$
\begin{aligned}
& \underset{\text { Lignin }}{\mathrm{C}_{9} \mathrm{H}_{10} \mathrm{O}_{4}} \rightarrow \underset{\text { Cresol }}{\mathrm{C}_{7} \mathrm{H}_{8} \mathrm{O}}+\mathrm{H}_{2} \mathrm{O}+2 \mathrm{CO} \Delta \mathrm{H}_{13}=-0.84 \mathrm{~kJ} / \mathrm{g} \\
& \underset{\text { Cresol }}{\mathrm{C}_{7} \mathrm{H}_{8} \mathrm{O}}+6.5 \mathrm{O}_{2} \rightarrow \underset{\text { acetic acid }}{\mathrm{C}_{2} \mathrm{H}_{4} \mathrm{O}_{2}}+5 \mathrm{CO}_{2}+2 \mathrm{H}_{2} \mathrm{O} \Delta \mathrm{H}_{14}=-25.57 \mathrm{~kJ} / \mathrm{g}
\end{aligned}
$$

Table 3

Chemical composition of clay and sand.

\begin{tabular}{lll}
\hline Oxide content $(w t \%)$ & Clay & Sand \\
\hline $\mathrm{SiO}_{2}$ & 50.3 & 62.4 \\
$\mathrm{Al}_{2} \mathrm{O}_{3}$ & 15.8 & 16.8 \\
$\mathrm{CaO}$ & 14.2 & 2.3 \\
$\mathrm{Fe}_{2} \mathrm{O}_{3}$ & 11.0 & 9.2 \\
$\mathrm{~K}_{2} \mathrm{O}$ & 3.4 & 4.3 \\
$\mathrm{MgO}$ & 2.2 & 2.0 \\
$\mathrm{Na}_{2} \mathrm{O}$ & 0.6 & 0.3 \\
\hline
\end{tabular}

$\Delta \mathrm{H}_{\text {lignin }}=-26.41 \mathrm{~kJ} / \mathrm{g}$

The decomposition of lignin is an exothermic reaction that generates heat especially between $350{ }^{\circ} \mathrm{C}$ and $500{ }^{\circ} \mathrm{C}$.

According to the values on Table 2 of $w t \%$ hemicellulose, wt $\%$ cellulose and $\mathrm{wt} \%$ lignin within WS and OCF respectively, the transformation energy of the thermal decomposition of WS was estimated at $\Delta \mathrm{H}(\mathrm{WS})=-18.12 \mathrm{~kJ} / \mathrm{g}$ and for OCF at $\Delta \mathrm{H}$ (OCF) $=-19.68 \mathrm{~kJ} / \mathrm{g}$.

\subsection{Clay characterization}

The clay is composed of illite, kaolinite, quartz, feldspars, calcite and hematite. As shown in Table 3, clay typically contains silicon dioxide percentages $\left(\mathrm{SiO}_{2}\right)$ between $50 \mathrm{wt} \%$ and $60 \mathrm{wt} \%$. The $\mathrm{SiO}_{2}$ content increases the porosity, but also the risk of cracking during cooling after firing (from $573{ }^{\circ} \mathrm{C}$ ). The second common chemical compound in clay, is $\mathrm{Al}_{2} \mathrm{O}_{3}$ and it presents $15.8 \mathrm{wt} \%$ (Table 3). During firing $\mathrm{CaCO}_{3}$ decomposes to produce $\mathrm{CO}_{2}$ and $\mathrm{CaO}$. The $\mathrm{CaO}$ released from $\mathrm{CaCO}_{3}$ decomposition can be combined with $\mathrm{SiO}_{2}$ to increase mechanical strength. The presence of $\mathrm{Fe}_{2} \mathrm{O}_{3}$ with $11.0 \mathrm{wt} \%$ can lead to the "black core" formation.

The presence of $\mathrm{Ca}$ and $\mathrm{Mg}$ oxides or hydroxides are not clearly shown in X-Ray Diffraction results (Fig. 3) mainly due to their low concentrations $(<10 \mathrm{wt} \%)$ and because their main diffraction peaks are masked by other major phase peaks (hematite, feldspars, quartz). The calcite decomposes at higher temperature $\left(830-870{ }^{\circ} \mathrm{C}\right)$ according to Boynton (Robert and Boynton, 1980). Ca from carbonates may act as melting agents, but it is reported to somehow limit the extent of vitrification at $T>1000{ }^{\circ} \mathrm{C}$. In fact, we observed that vitrification is more extended at higher $\mathrm{T}$ when no carbonates exist.

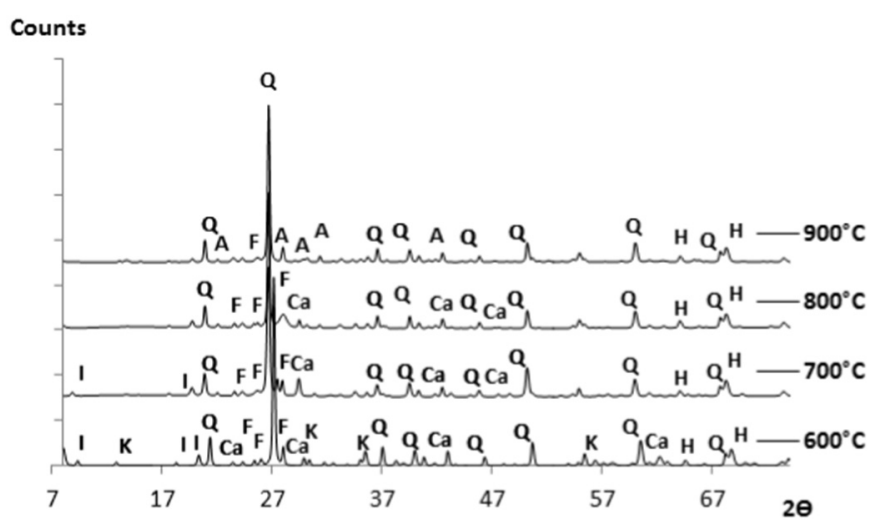

Fig. 3. XRD of clay body from $600{ }^{\circ} \mathrm{C}$ to $900{ }^{\circ} \mathrm{C}, \mathrm{Q}=$ Quartz; $\mathrm{I}=$ illite; $\mathrm{K}=$ kaolinite; $\mathrm{F}=$ feldspar; $\mathrm{Ca}=$ Calcite; $\mathrm{G}=$ gehlenite; $\mathrm{H}=$ hematite; $\mathrm{A}=$ anorthite. 


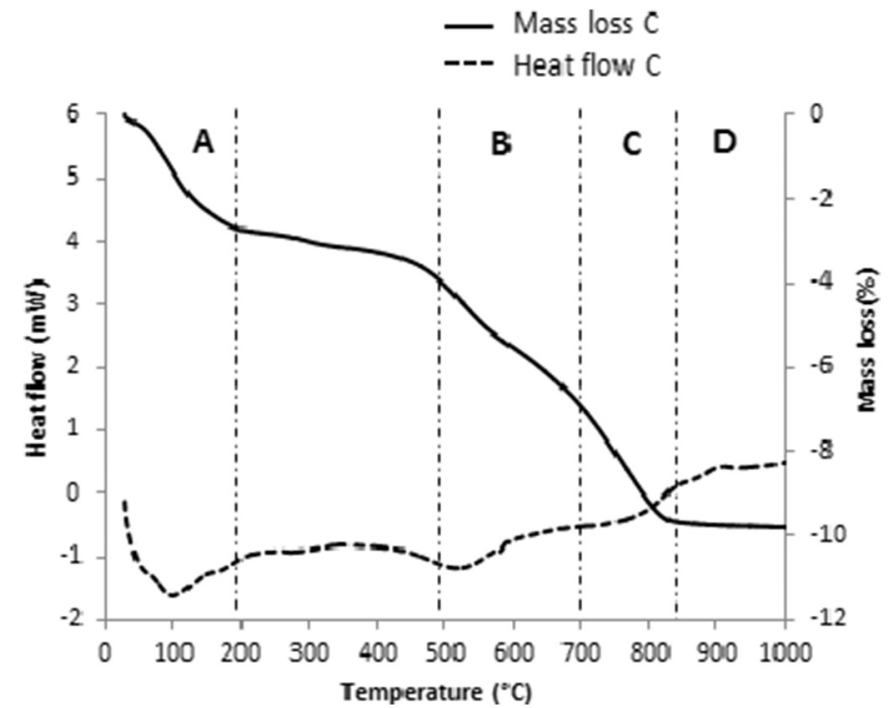

Fig. 4. TGA-DTA curves of clay body.

$$
\begin{aligned}
& \underset{\text { calcite }}{\mathrm{CaCO}_{3}} \rightarrow \underset{\text { lime }}{\mathrm{CaO}}+\underset{\text { carbon dioxide }}{\mathrm{CO}_{2}} \\
& \left.\underset{\text { feldspar }}{2\left(\mathrm{KAl}_{3} \mathrm{Si}_{3} \mathrm{O}_{11}\right.}\right)+\underset{\text { calcite }}{6\left(\mathrm{CaCO}_{3}\right)} \rightarrow \underset{\text { gehlenite }}{3\left(\mathrm{Ca}_{2} \mathrm{Al}_{2} \mathrm{SiO}_{7}\right)}+\underset{\text { carbon dioxide }}{6\left(\mathrm{CO}_{2}\right)}+\underset{\text { quartz }}{3\left(\mathrm{SiO}_{2}\right)}+\underset{\text { potassium oxide }}{\mathrm{K}_{2} \mathrm{O}}
\end{aligned}
$$

The Fig. 4. showed clearly the evaporation of residual water remaining interposed between the clay particles before $100{ }^{\circ} \mathrm{C}(\mathrm{A})$, this first mass loss area reached its maximum of $2 \mathrm{wt} \%$ at $100{ }^{\circ} \mathrm{C}$ by eliminating of the hygroscopic water. Then a mass loss of $2.5 \mathrm{wt} \%$ occurred between $500{ }^{\circ} \mathrm{C}$ and $700{ }^{\circ} \mathrm{C}$ (B) was associated with the formation of metakaolinite (reaction (10)). The dehydroxylated clay mineral residues were combined with calcium carbonates leading to the formation of lime and oxidation of sulfates to sulfides (Cultrone et al., 2004b). For the clay material rich in calcium carbonates a significant mass loss of $3 \mathrm{wt} \%$ due to decarbonatation extended up to $850{ }^{\circ} \mathrm{C}$ (C) with the release of $\mathrm{CO}_{2}$ is observed.

According to the DTA curve presented in Fig. 4, the clay body showed an endothermic peak related to the water evaporation as shown in TGA curve (A). The second endothermic peak was associated with the dehydroxylation of clay body between $500{ }^{\circ} \mathrm{C}$ and $700{ }^{\circ} \mathrm{C}$ (B). kaolinite was transformed to amorphous metakaolinite at $500{ }^{\circ} \mathrm{C}$ by removal of the hydroxyl groups of the silicate lattice (Guggenheim et al., 1987; Toledo et al., 2004) according to the reaction (11). At $600{ }^{\circ} \mathrm{C}$ illite decomposed to the dehydroxylated illite and liberated a water vapor (reaction (12)). A dehydroxylated phyllosilicate phase, structurally different to the hydrated one (Guggenheim et al., 1987), is reported to exist up to $950{ }^{\circ} \mathrm{C}$ when complete breakdown of the dehydroxylated illite occurs (Peters and Iberg, 1978). Between $700{ }^{\circ} \mathrm{C}$ and $850{ }^{\circ} \mathrm{C}$ the calcium carbonate (calcite) was decomposed to $\mathrm{CaO}$ (lime) with release of $\mathrm{CO}_{2}$ and formation of gehlenite (reaction (10)). The reaction (9) was presented with an endothermic peak between $700{ }^{\circ} \mathrm{C}$ and $850{ }^{\circ} \mathrm{C}$ (C) on the DTA curve. Beyond $850{ }^{\circ} \mathrm{C}$ (D) we observed a vitrification of clay and it came more extended at higher temperature when no carbonates exist.

$$
\begin{aligned}
& \underset{\text { kaolinite }}{\mathrm{Al}_{2} \mathrm{Si}_{2} \mathrm{O}_{5}(\mathrm{OH})_{4}} \rightarrow \underset{\text { metakaolinite }}{\mathrm{Al}_{2} \mathrm{Si}_{2} \mathrm{O}_{7}}+\underset{\text { water vapor }}{2\left(\mathrm{H}_{2} \mathrm{O}\right)} \\
& \underset{\text { illite }}{\mathrm{KAl}_{3} \mathrm{Si}_{3} \mathrm{O}_{10}(\mathrm{OH})_{2}} \rightarrow \underset{\text { dehydroxylated illite }}{\mathrm{KAl}_{3} \mathrm{Si}_{3} \mathrm{O}_{11}}+\underset{\text { water vapor }}{\mathrm{H}_{2} \mathrm{O}}
\end{aligned}
$$

The estimation of energy of transformation of each reaction associated with the clay body decomposition was determined by the same method explained in the literature (Lide, 2005). The enthalpy of formation of the minerals was used from the literature (Ferrer et al., 2015; Hirono and Tanikawa, 2011; Holland and Powell, 2011).
Table 4

Quantification of crystalline phases of clay body at $600{ }^{\circ} \mathrm{C}$ by RIR method and enthalpies of reaction calculated from the enthalpies of formation.

\begin{tabular}{lll}
\hline Crystalline phases & \%Weight of crystalline phase & Enthalpy H (kJ/g) \\
\hline Calcite & 11 & 1796 (reaction 10) \\
Kaolinite & 9 & 1158 (reaction 12) \\
Illite & 13 & 374 (reaction 13) \\
Quartz & 52 & 11.7 \\
Potassium feldspar & 11 & 207 \\
\hline
\end{tabular}

As shown previously with the TGA-DTA curves (Fig. 4), the heat of reaction depended mainly on the clay mineral thermal decomposition: the carbonate decomposition and dehydroxylation of kaolinite and illite respectively.

According to the values of $w \mathrm{t} \%$ Calcite, wt $\%$ Kaolinite and wt $\%$ Illite of clay quantified by the RIR method (Table 4), the transformation energy of the thermal decomposition of Clay was estimated at $\Delta H(C)$ $=0.35 \mathrm{~kJ} / \mathrm{g}$.

\subsection{Characterization of fired clay ceramics}

\subsubsection{Thermal and mechanical properties}

The samples of clay with and without agro-wastes were dried and fired. Several measures were carried out to evaluate the thermal and mechanical properties of the fired clay samples with and without agrowastes.

The thermal insulation of fired clay ceramics was influenced by the pore formation due to the thermal decomposition of agro-wastes into the clay body. For the samples of clay without agro-wastes, the thermal conductivity was found to be $0.5 \mathrm{~W} / \mathrm{m} . \mathrm{K}$ (Table 5). A low thermal conductivity was obtained by the samples of clay incorporated WS and OCF respectively. Table 5 shows that for $\mathrm{C}-4 \mathrm{wt} \% \mathrm{OCF}$ and $\mathrm{C}-8 \mathrm{wt} \% \mathrm{OCF}$ their values of thermal conductivity $(\lambda)$ were decreased by $16 \%$ and $28 \%$ in comparison with the one of fired clay ceramic respectively. Increasing the amount of WS and OCF contributes to decrease the thermal conductivity of samples respectively. Adding WS into the clay body has shown also a decreasing of $\lambda$ by $20 \%$ and $30 \%$ for C-3wt $\%$ WS and C-7wt\%WS respectively.

Number of studies (Demir, 2008; Khedari et al., 2004; Onésippe et al., 2010) has discussed the impact of porosity generated by agrowastes in the clay body to the thermal properties. These authors showed that the thermal decomposition of additives into the clay body led to pore formation then to an improving of the thermal insulation of ceramic materials. (Demir, 2008) demonstrated that organic residues can be used as a type of pore-forming additive in the clay body without any damaging effect on the other brick manufacturing parameters.

Also, the pore formation has an effect on the mechanical strength. Adding $3 \mathrm{wt} \%$ of WS into the clay body contributes to the diminution of the bending stress compared to the fired clay bricks without using agrowastes (Table 5). The samples using OCF showed a mechanical strength higher than those using WS. These results may be related to the pores

Table 5

Thermal and mechanical properties of fired clay bricks using agro-wastes.

\begin{tabular}{lll}
\hline & Thermal conductivity, $\lambda(\mathrm{W} / \mathrm{m} \cdot \mathrm{K})$ & $\begin{array}{l}\text { Fired-bending stress, } \sigma \\
(\mathrm{MPa})\end{array}$ \\
\hline $\mathrm{C}$ & 0.50 & 11.45 \\
$\mathrm{C}-4 \mathrm{wt} \%$ OCF & 0.42 & 11.23 \\
$\mathrm{C}-8 \mathrm{wt} \%$ OCF & 0.36 & 8.50 \\
$\mathrm{C}-3 \mathrm{wt} \%$ WS & 0.40 & 11.02 \\
$\mathrm{C}-7 \mathrm{wt} \%$ WS & 0.35 & 7.65 \\
\hline
\end{tabular}


sizes created into the clay body (Aouba et al., 2016; Wagh et al., 1991; Yakub et al., 2012).

The porosity increment leads to decrease thermal conductivity also has an impact on mechanical strength. However, the impact of using OCF is not considered as negative according to the industrial standards which recommend at least $8 \mathrm{MPa}$.

\subsubsection{Energy savings}

The energy savings related to the decomposition of bricks raw materials was investigated.

The thermal behavior of the clay incorporated by olive core flour showed a combination of behavior of two respective elements to temperature. Firstly, the evaporation of water (A) was slightly changed which is associated with the amount of OCF incorporation into the clay body. The TGA curves showed a slight mass loss of $2.9 \mathrm{wt} \%$ and $3.14 \mathrm{wt}$ $\%$ for C- $4 \mathrm{wt} \% \mathrm{OCF}$ and $\mathrm{C}-8 \mathrm{wt} \% \mathrm{OCF}$ respectively (A). The OCF is very hygroscopic, the amounts of water that they hold vary very easily and quickly. The OCF added to the clay was decomposed completely between $200{ }^{\circ} \mathrm{C}$ and $450{ }^{\circ} \mathrm{C}$ (B). The dehydroxylation of clay body (C) was associated with a mass loss of $2.41 \mathrm{wt} \%$ and $3.31 \mathrm{wt} \%$ for C- $4 \mathrm{wt} \%$ OCF and C-8wt $\% \mathrm{OCF}$, respectively. The decarbonatation of clay was indicated from $700{ }^{\circ} \mathrm{C}$ to $850{ }^{\circ} \mathrm{C}$ (D) and was superimposed with the thermal behavior of OCF without significant disturbance. The increase of OCF amount into the clay body increased the degradation of the mixture. In zone (E) no mass loss was observed which is associated with the formation of stable crystalline phases of clay body.

The same behavior was observed with C-3wt $\% \mathrm{WS}$ and C-7wt $\% \mathrm{WS}$ (Fig. 6). The clay and WS showed the release of absorbed water up to $200{ }^{\circ} \mathrm{C}$ (A). This dehydration was quantified by a mass loss of $4 \%$. Between $250{ }^{\circ} \mathrm{C}$ and $450{ }^{\circ} \mathrm{C}$ (B), the mass loss of $3 \mathrm{wt} \%$ and $4 \mathrm{wt} \%$ were observed for $\mathrm{C}-3 \mathrm{wt} \% \mathrm{WS}$ and $\mathrm{C}-7 \mathrm{wt} \% \mathrm{WS}$, respectively. This mass loss can be attributed to the combustion of WS. The dehydroxylation of clay body was observed between $500{ }^{\circ} \mathrm{C}$ and $700{ }^{\circ} \mathrm{C}(\mathrm{C})$ with a mass loss of $2.23 \mathrm{wt} \%$ and $3.05 \mathrm{wt} \%$ for respectively $\mathrm{C}-3 \mathrm{wt} \% \mathrm{WS}$ and $\mathrm{C}-7 \mathrm{wt} \% \mathrm{WS}$. The decomposition of calcium carbonates was showed by a mass loss of $4 \mathrm{wt} \%$ (D). In zone (E) no mass loss was observed which is associated with the formation of stable crystalline phases of clay body.

The DTA curves of the clay incorporating OCF (Fig. 7) respectively $4 \mathrm{wt} \%$ and $8 \mathrm{wt} \%$, showed an exothermic peak extending between $250{ }^{\circ} \mathrm{C}$ to $450{ }^{\circ} \mathrm{C}$ (B). This degradation was associated with the amount of OCF incorporation into the clay body.

For the C-3wt \%WS and C-7wt\%WS (Fig. 8), the exothermic peak areas $\left(200-500{ }^{\circ} \mathrm{C}\right)$ showed the increase in the amount of heat released from WS. In fact, the incorporation of biomass has valued the heat flow dissipated occurring the firing stage. One of the challenges of this study was to quantify this energy released.

In the industrial kiln, energy of $2.2 \mathrm{~kJ} / \mathrm{g}$ is needed in the firing step of clay without agro-wastes. This energy needed includes the energy absorbed by the transformation of clay (dehydroxylation and decarbonatation). The energy transformation associated with clay was estimated previously in this paper at $\Delta \mathrm{H}(\mathrm{C})=0.35 \mathrm{~kJ} / \mathrm{g}$ (section 3.2). So, this energy presents $21.8 \%$ of the energy needed in the firing step $(2.2 \mathrm{~kJ} / \mathrm{g})$. The TGA-DTA analyses as shown previously (Fig. 5, Fig. 6) indicated thermal events, especially the agro-wastes thermal decomposition (WS and OCF) into the clay body during firing step. Indeed, the energy saving related to the incorporation of agro-wastes into the clay body was estimated using the energy transformation of clay body and agro-wastes respectively using Eq. ((14), ((15) and (16).

$\mathrm{ER}(\mathrm{C}-\mathrm{Xwt} \% \mathrm{OCF}$ or $\mathrm{WS})=\mathrm{Xwt} \%(\mathrm{OCF}$ or WS $) \cdot \Delta \mathrm{H}(\mathrm{OCF}$ or WS $)$

$\mathrm{EA}(\mathrm{C}-\mathrm{Xwt} \% \mathrm{OCF}$ or $\mathrm{WS})=\mathrm{Ywt} \%(\mathrm{C}) \cdot \Delta \mathrm{H}(\mathrm{C})$

Where Xwt\% is the amount of OCF or WS in the clay body and Ywt $\%$ is the amount of clay body in the mixture of clay incorporated OCF or WS (C-Xwt\%OCF or WS).

So, the energy saving (ES) of each sample of clay incorporated WS

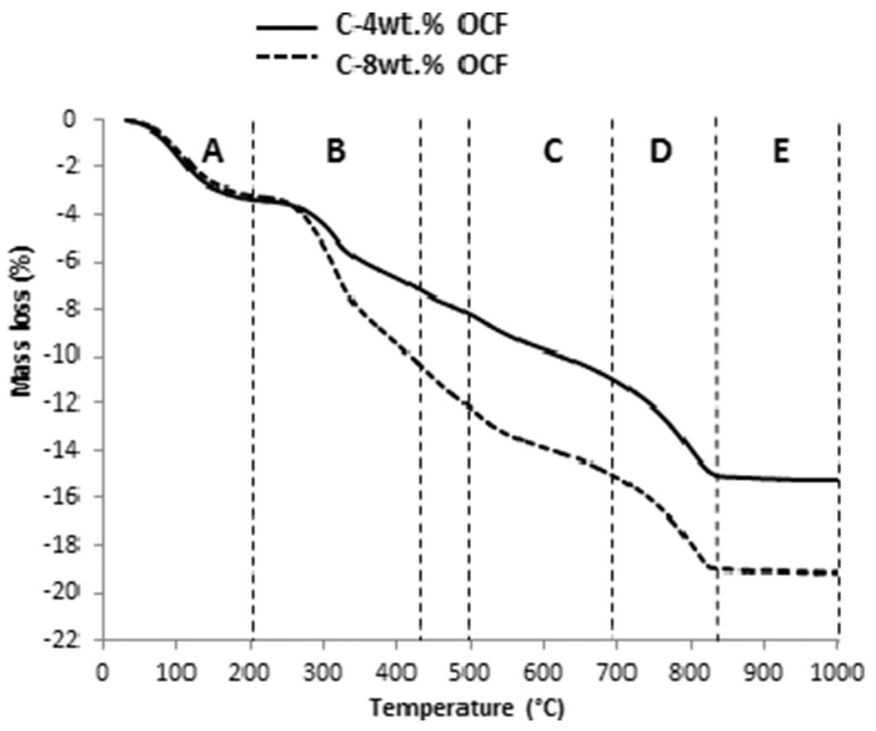

Fig. 5. TGA curves of clay incorporated by $4 \mathrm{wt} \%$ and $8 \mathrm{wt} \%$ OCF.

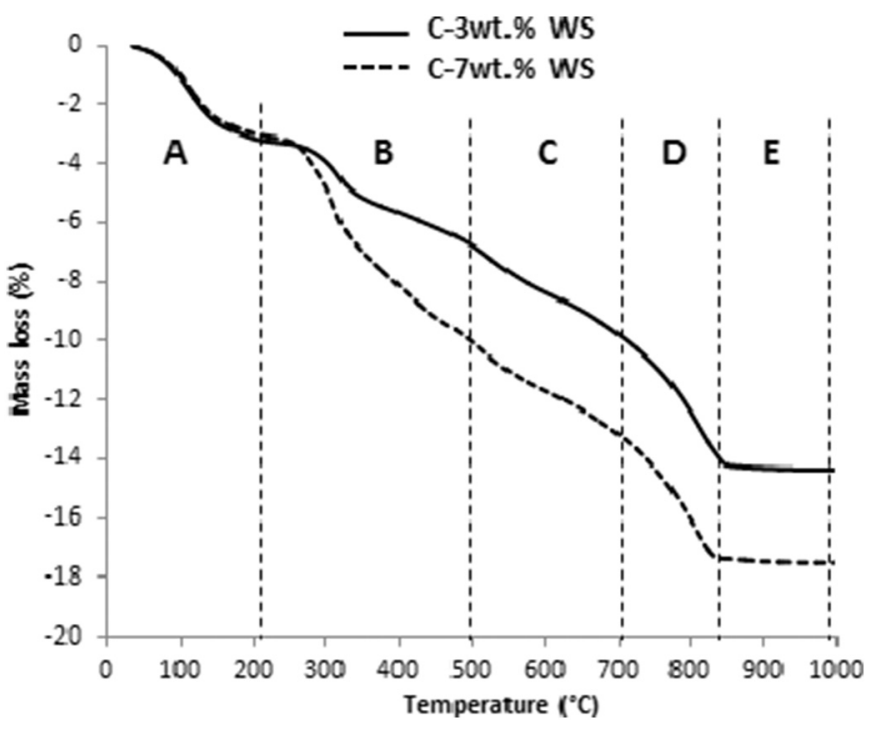

Fig. 6. TGA curves of clay incorporated by $3 \mathrm{wt} \%$ and $7 \mathrm{wt} \% \mathrm{WS}$.

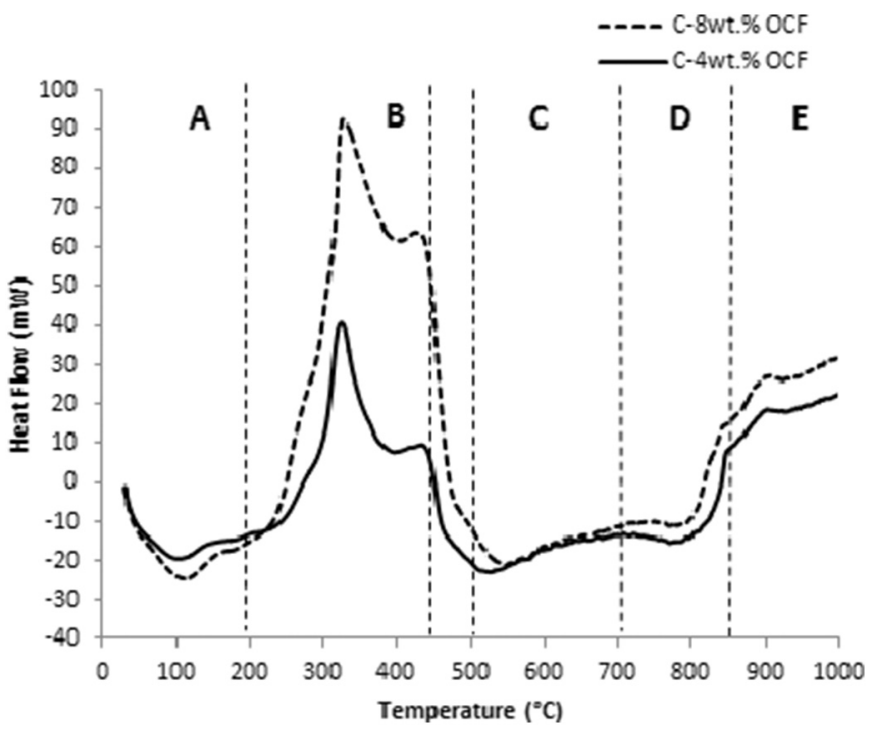

Fig. 7. DTA curves of clay incorporated by $4 \mathrm{wt} \%$ and $8 \mathrm{wt} \%$ OCF. 


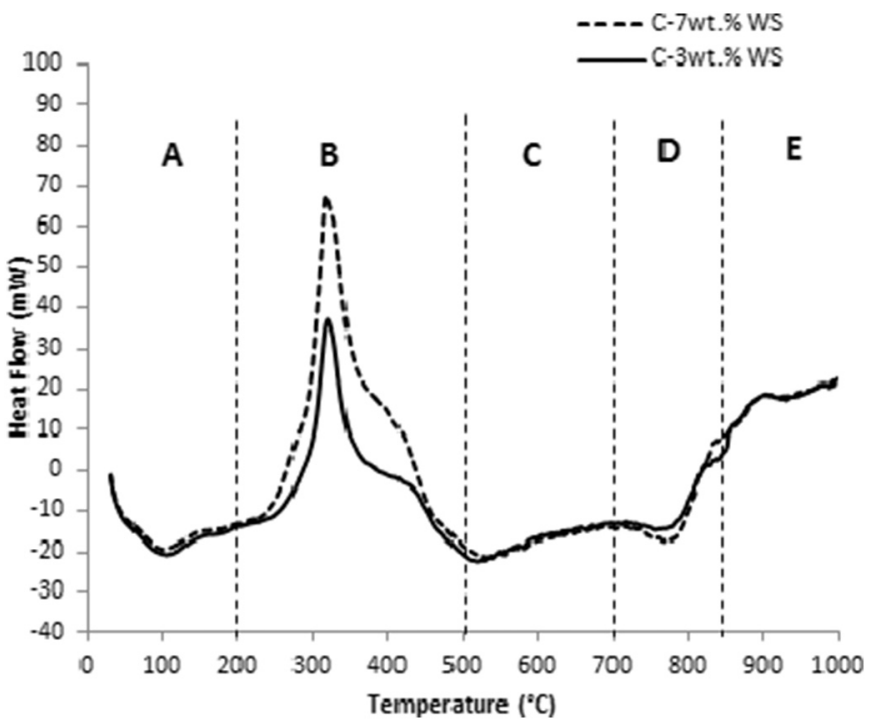

Fig. 8. DTA curves of clay incorporated by $3 \mathrm{wt} \%$ and $7 \mathrm{wt} \%$ WS.

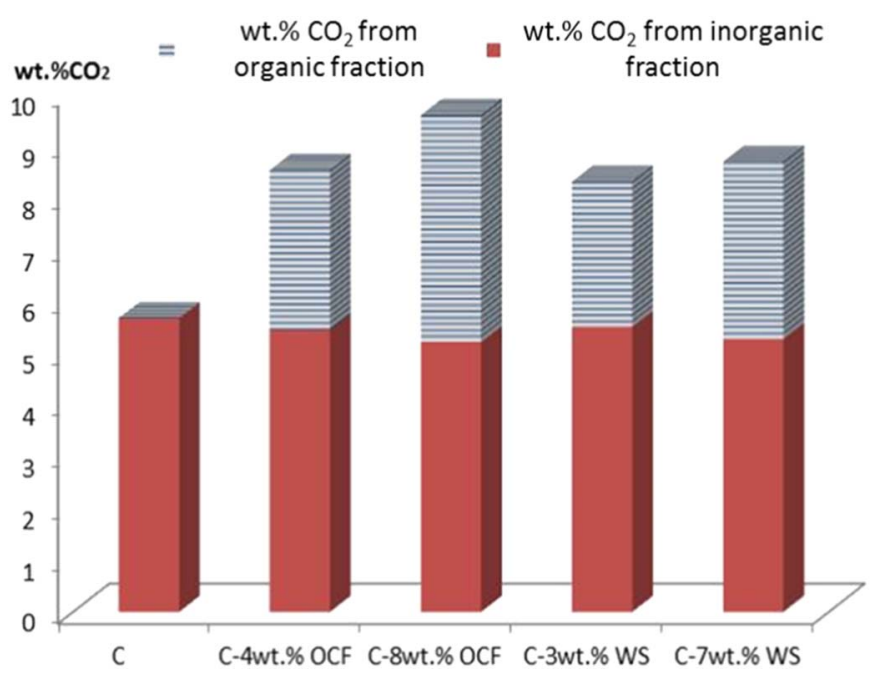

Fig. 9. $\% \mathrm{CO}_{2}$ emission of clay body, C-Xwt $\% \mathrm{OCF}$ and $\mathrm{C}-\mathrm{Xwt} \% \mathrm{WS}$.

or OCF is calculated using Eq. (16).

$$
\begin{aligned}
\mathrm{ES}= & 100 \cdot(\mathrm{EA}(\mathrm{C})-\mathrm{EA}(\mathrm{C}-\mathrm{Xwt} \% \mathrm{OCF} \text { orWS }) \\
& +\mathrm{ER}(\mathrm{C}-\mathrm{Xw} \% \mathrm{OCF} \text { (WW })) /(\text { Energy needed })
\end{aligned}
$$

Where EA(C) is the energy absorbed related to the decomposion of clay body, EA(C-Xwt\%OCF or WS) is the energy absorbed associated with the decomposition of clay body incorporated Xwt $\%$ OCF or Xwt $\%$ WS, and ER(C-Xwt\%OCF or WS) is the energy released associated with the decomposion of clay incorporated $\mathrm{Xwt} \% \mathrm{OCF}$ or $\mathrm{Xwt} \% \mathrm{WS}$.

The energy consumption of the production of clay bricks was decreased by adding agro-wastes into the clay matrix. Particularly, with using OCF witch showed an energy saving to $36 \%$ and to $72 \%$ with incorporating $4 \mathrm{wt} \%$ and $8 \mathrm{wt} \%$ of OCF respectively.

\subsubsection{Other $\mathrm{CO}_{2}$ environmental indicators}

In order to determine the environmental impact of OCF and WS incorporation into the clay body during firing step, the Micro-GC was used to quantify gas emission with a specific database, in particular, $\mathrm{CO}_{2}$ emission. In fact, firing clay samples were made on the fixed bed reactor named Carbolite in the laboratory scale. So, only $\mathrm{CO}_{2}$ coming from the decomposition of biomass namely $\mathrm{CO}_{2}$ from organic fraction and $\mathrm{CO}_{2}$ coming from the decarbonatation of clay namely $\mathrm{CO}_{2}$ from inorganic fraction were be quantified. The $\mathrm{CO}_{2}$ related to fuel or other source of energy in the firing stage was not taken into account in this study and is a subject of ongoing tails at full scale. The main objective in this work is to quantify the $\mathrm{CO}_{2}$ emission related to the raw materials of clay bricks.

According to the thermogravimetric analyses shown previously in this paper of the C-Xwt\%OCF and C-Xwt\%WS, the dehydroxylation and decarbonatation were detected respectively at $500-650{ }^{\circ} \mathrm{C}$ and $750-830^{\circ} \mathrm{C}$ (Fig. 5, Fig. 6). For the OCF and WS their thermal decompositions were observed in a temperature range of $200-500{ }^{\circ} \mathrm{C}$ (Fig.1, Fig. 2).

The combustion of the samples was performed in the fixed bed reactor named Carbolite using $22 \mathrm{~g}$ with a flow rate of $\mathrm{Q}_{\text {air }}=4 \mathrm{NL} / \mathrm{h}$.

With a constant rate throughout the experiment

$\mathrm{Q}_{\text {air }}=4 \mathrm{NL} / \mathrm{h}$, so: $\mathrm{Q}_{(\mathrm{N} 2)}=0.79 \cdot \mathrm{Q}_{\text {air }}$

The total flow is: $\mathrm{QTotal}=\mathrm{Q}(\mathrm{N} 2) / \% \mathrm{~N} 2 \quad(\mathrm{~L} / \mathrm{h})$ $\% \mathrm{~N}_{2}$.

The volume percentage of nitrogen was measured by the microGC:

This means that the total volume of recovered gas is:

VTotal $=$ QTotal $\cdot \mathrm{t} \quad(\mathrm{L})$

Where $t$ is the time of the thermal decomposition of sample in the fixed bed reactor. To quantify the carbon dioxide volume $\mathrm{V}_{\mathrm{CO} 2}$, the following equations are used:

$\mathrm{V}(\mathrm{CO} 2)=\% \mathrm{CO} 2 \cdot \mathrm{VTotal}(\mathrm{L})$

$\mathrm{mCO} 2=\mathrm{VCO} 2 \cdot \mathrm{MCO} 2 / 22.4(\mathrm{~g})$

In terms of energy content, biomass is known to have the HHV between 17 and $21 \mathrm{~kJ} / \mathrm{g}$. The combustion of biomass produced an atmospheric aerosol characterized by significant organic fraction (Fig. 9). The organic compounds resulting from the degradation of cellulose and hemicellulose, such as levoglucosan and galactosan but also methoxyphenols from the pyrolysis of lignin are widely used to evaluate the impact of the biomass combustion.

The TGA curves shown previously in this paper indicated that only a small content of ash was produced from the combustion of biomass (WS and OCF). The ashes often contain more potassium and silicon in particular involved in the decrease in melting temperature. It is then possible to fuse ash at $700{ }^{\circ} \mathrm{C}$, resulting from the decarbonatation of clay body and dysfunction of the equipment. The main gas such as carbon dioxide emission is from cellulose which decomposes into levoglucosan (Fig. 9).

The Table 8 presents the $\mathrm{CO}_{2}$ emission factors related to the decomposition of biomass $\left(\mathrm{CO}_{2}\right.$ from organic fraction) and the decarbonatation of clay body ( $\mathrm{CO}_{2}$ from inorganic fraction), respectively. The $\mathrm{CO}_{2}$ emission factor associated with fuel or source of heat are not included. These environmental indicators, the $\mathrm{CO}_{2}$ emission factors related to the decomposition of brick raw materials could be used as a data in the ceramic manufacturing.

Adding biomass (WS and OCF) into clay body results energy savings

Table 6

Energy saving from different amounts of biomass incorporation into clay matrix.

\begin{tabular}{llll}
\hline & $\begin{array}{l}\text { Energy released ER } \\
(\mathrm{kJ} / \mathrm{g})\end{array}$ & $\begin{array}{l}\text { Energy absorbed } \\
\mathrm{EA}(\mathrm{kJ} / \mathrm{g})\end{array}$ & $\begin{array}{l}\text { Energy saving ES } \\
(\%)\end{array}$ \\
\hline $\mathrm{C}$ & - & 0.35 & - \\
$\mathrm{C}-4 \mathrm{wt} \%$ & 0.78 & 0.33 & $36 \pm 0.3$ \\
$\begin{array}{r}\text { OCF } \\
\mathrm{C}-8 \mathrm{wt} \%\end{array}$ & 1.57 & 0.32 & $72 \pm 0.7$ \\
$\begin{array}{l}\text { OCF } \\
\mathrm{C}-3 \mathrm{wt} \% \text { WS }\end{array}$ & 0.54 & 0.34 & $25 \pm 0.0$ \\
$\mathrm{C}-7 \mathrm{wt} \%$ WS & 1.26 & 0.32 & $58 \pm 0.6$ \\
\hline
\end{tabular}


Table 7

$\mathrm{CO}_{2}$ from inorganic fraction saving by adding biomass into the clay body.

\begin{tabular}{llll}
\hline & $\begin{array}{l}\text { \%wt } \mathrm{CO}_{2} \text { from } \\
\text { organic fraction }\end{array}$ & $\begin{array}{l}\text { \%wt } \mathrm{CO}_{2} \text { from } \\
\text { inorganic fraction }\end{array}$ & $\begin{array}{l}\mathrm{CO}_{2} \text { from inorganic } \\
\text { fraction saving (\%) }\end{array}$ \\
\hline $\mathrm{C}$ & - & 5.67 & - \\
$\mathrm{C}-4 \mathrm{wt} \%$ & 3.09 & 5.44 & 4.06 \\
$\begin{array}{r}\mathrm{OCF} \\
\mathrm{C}-8 \mathrm{wt} \% \\
\text { OCF }\end{array}$ & 4.38 & 5.21 & 8.11 \\
$\begin{aligned} \mathrm{C}-3 \mathrm{wt} \% \\
\mathrm{WS}\end{aligned}$ & 2.81 & 5.5 & 3.00 \\
$\mathrm{C}-7 \mathrm{wt} \%$ & 3.42 & 5.27 & 7.05 \\
$\mathrm{WS}$ & & & \\
\hline
\end{tabular}

Table 8

$\mathrm{CO}_{2}$ from organic fraction emission factor and $\mathrm{CO}_{2}$ from inorganic emission factor in this study.

\begin{tabular}{rll}
\hline & $\begin{array}{l}\mathrm{CO}_{2} \text { from organic fraction } \\
\text { emission factor }\left(\mathrm{g} \text { of } \mathrm{CO}_{2} / \mathrm{kg} \text { of }\right. \\
\text { brick) }\end{array}$ & $\begin{array}{l}\mathrm{CO}_{2} \text { from inorganic fraction } \\
\text { emission factor }\left(\mathrm{g} \text { of } \mathrm{CO}_{2} / \mathrm{kg} \text { of }\right. \\
\text { brick) }\end{array}$ \\
\hline $\mathrm{C} \quad 0$ & 56.7 \\
$\mathrm{C}-4 \mathrm{wt} \%$ & 30.9 & 54.4 \\
OCF & & 52.1 \\
$\mathrm{C}-8 \mathrm{wt} \%$ & 43.8 & \\
OCF & 28.1 & 55.0 \\
$\mathrm{C}-3 \mathrm{wt} \%$ & & 52.7 \\
$\mathrm{WS}$ & 34.2 & \\
$\mathrm{C}-7 \mathrm{wt} \%$ & & \\
$\mathrm{WS}$ & &
\end{tabular}

by its thermal decomposition (Table 6) and leads to decrease the $\mathrm{CO}_{2}$ emission coming from the clay body as shown in the following Table 7.

Those emissions factors can be included in the database for the calculation of life cycle inventories in ceramic industry, for these cases where biomass is used as part of raw material. The application of this type of practices in the ceramic industry will contribute to economic, social and environmental benefits of the life cycle by using a renewable resource and waste instead a natural resource such as clay and consume much less energy from fossil sources.

\section{Conclusion}

This paper demonstrated that the reuse of agro-wastes as a raw material in ceramic industry contributed to both profitable thermal properties and environmental benefits. The results showed that adding agro-wastes into clay body contributed to improving the thermal properties without negative impact on the mechanical properties of ceramic materials. Also, three environmental indicators have been presented in this work, namely: energy saving, $\mathrm{CO}_{2}$ from organic fraction emission factor coming from the decomposition of agro-wastes and $\mathrm{CO}_{2}$ from inorganic fraction emission factor related to the decarbonatation of clay body.

On one hand, the thermal insulation of fired clay bricks was influenced by the pore formation due to the thermal decomposition of agro-wastes into the clay body. Adding WS and OCF into clay body showed a decreasing of thermal conductivity by 16 to $30 \%$ for clay incorporated OCF $(4,8 \mathrm{wt} \%)$ and WS $(3,7 \mathrm{wt} \%)$ respectively. On other hand, adding $3 \mathrm{wt} \%$ and $7 \mathrm{wt} \%$ of WS into the clay body respectively, contributes to diminution of the bending stress compared to the fired clay bricks without agro-wastes. The impact of using OCF was not considered negative in order to have a compromising between the thermal insulation and the mechanical strength of ceramic materials.

The TGA-DTA analyses provided an approach to determine the heat reaction of thermal decomposition of OCF, WS and clay bricks incorporated agro-wastes (OCF and WS) respectively. The higher heating values were added by self-combustion within the clay mixture so less energy is needed to fire the bricks. Then, the energy consumption of manufacturing bricks decreased to above $36 \%$ with incorporating $4 \mathrm{wt} \%$ of OCF into the clay body. So, the addition of agro-wastes into clay body has been demonstrated to be efficient for energy savings in the clay bricks manufacturing. This study has also established the difference between the $\mathrm{CO}_{2}$ released from inorganic source such as $\mathrm{CaCO}_{3}$ (clay) and the one released from organic source (agro-wastes). The results confirmed that adding the agro-wastes into clay body lead to decrease the firing rejects by decreasing the inorganic $\mathrm{CO}_{2}$ emission coming from the dacarbonatation of clay body. The $\mathrm{CO}_{2}$ emission factors related to the decomposition of agro-wastes (organic) and the decarbonatation of clay (inorganic) respectively could be used as environmental indicators in the database in the ceramic manufacturing. The recycling of agro-wastes as a sustainable construction material seems to be feasible solution, not only to pollution problem but also an economical option to produce green buildings.

\section{Acknowledgment}

The authors would like to thank l'Agence Nationale de la Recherche (ANR) under the grant LabCom $\mathrm{N}^{\circ} 40093$. The authors would like to acknowledge the TERREAL Company for financial support and scientific contribution to this study. We also thank the staff of ARETERRIS for assistance with the research. We would also like to show our gratitude to Pr. Pastora Maria Bello Bugallo from School of Engineering, University of Santiago de Compostela, Spain, who provided insight and expertise that greatly assisted this work. Also, Dr. Pierre-Marie NIGAY from Université de Toulouse, Mines Albi, CNRS, Centre RAPSODEE, Campus Jarlard, Route de Teillet, F-81013 Albi Cedex 09, France.

\section{References}

Aouba, L., Bories, C., Coutand, M., Perrin, B., Lemercier, H., 2016. Properties of fired clay bricks with incorporated biomasses: cases of olive stone flour and wheat straw residues. Constr. Build. Mater. 102, 7-13.

Bories, C., Borredon, M.-E., Vedrenne, E., Vilarem, G., 2014. Development of eco-friendly porous fired clay bricks using pore-forming agents: a review. J. Environ. Manag. 143, 186-196.

Bories, C., Aouba, L., Vedrenne, E., Vilarem, G., 2015. Fired clay bricks using agricultural biomass wastes: study and characterization. Constr. Build. Mater. 91, 158-163.

Cultrone, G., Sebastián, E., Elert, K., de la Torre, M.J., Cazalla, O., Rodriguez-Navarro, C., 2004. Influence of mineralogy and firing temperature on the porosity of bricks. J. Eur. Ceram. Soc. 24, 547-564.

Demir, I., 2006. An investigation on the production of construction brick with processed waste tea. Build. Environ. 41, 1274-1278.

Demir, I., 2008. Effect of organic residues addition on the technological properties of clay bricks. Waste Manag. 28, 622-627.

Diblasi, C., 2008. Modeling chemical and physical processes of wood and biomass pyrolysis. Prog. Energy Combust. Sci. 34, 47-90.

Faria, K.C.P., Gurgel, R.F., Holanda, J.N.F., 2012. Recycling of sugarcane bagasse ash waste in the production of clay bricks. J. Environ. Manag. 101, 7-12.

Fateh, T., Rogaume, T., Luche, J., Richard, F., Jabouille, F., 2013. Kinetic and mechanism of the thermal degradation of a plywood by using thermogravimetry and Fouriertransformed infrared spectroscopy analysis in nitrogen and air atmosphere. Fire Saf. J. 58, 25-37.

Ferrer, S., Mezquita, A., Gomez-Tena, M.P., Machi, C., Monfort, E., 2015. Estimation of the heat of reaction in traditional ceramic compositions. Appl. Clay Sci. 108, 28-39.

Freyburg, S., Schwarz, A., 2007. Influence of the clay type on the pore structure of structural ceramics. J. Eur. Ceram. Soc. 27, 1727-1733.

González, I., Galán, E., Miras, A., Vázquez, M.A., 2011. $\mathrm{CO}_{2}$ emissions derived from raw materials used in brick factories. Applications to Andalusia (Southern Spain). Appl. Clay Sci. 52, 193-198.

Gualtieri, M.L., Gualtieri, A.F., Gagliardi, S., Ruffini, P., Ferrari, R., Hanuskova, M., 2010. Thermal conductivity of fired clays: effects of mineralogical and physical properties of the raw materials. Appl. Clay Sci. 49, 269-275.

Guggenheim, S., Chang, Y.-H., Van Groos, A.F.K., 1987. Muscovite dehydroxylation: hightemperature studies. Am. Mineral. 72, 537-550.

Hirono, T., Tanikawa, W., 2011. Implications of the thermal properties and kinetic parameters of dehydroxylation of mica minerals for fault weakening, frictional heating, and earthquake energetics. Earth Planet. Sci. Lett. 307, 161-172.

Holland, T.J.B., Powell, R., 2011. An improved and extended internally consistent thermodynamic dataset for phases of petrological interest, involving a new equation of state for solids: thermodynamic dataset for phases of petrological interest. J. Metamorph. Geol. 29, 333-383.

Khedari, J., Nankongnab, N., Hirunlabh, J., Teekasap, S., 2004. New low-cost insulation particleboards from mixture of durian peel and coconut coir. Build. Environ. 39, 
59-65.

Koroneos, C., Dompros, A., 2007. Environmental assessment of brick production in Greece. Build. Environ. 42, 2114-2123.

Lide, D.R., 2005. CRC Handbook of Chemistry and Physics. CRC Press.

López-González, D., Fernandez-Lopez, M., Valverde, J.L., Sanchez-Silva, L., 2013.

Thermogravimetric-mass spectrometric analysis on combustion of lignocellulosic biomass. Bioresour. Technol. 143, 562-574.

Madurwar, M.V., Ralegaonkar, R.V., Mandavgane, S.A., 2013. Application of agro-waste for sustainable construction materials: a review. Constr. Build Mater. 38, 872-878.

Muñoz Velasco, P., Morales Ortíz, M.P., Mendívil Giró, M.A., Muñoz Velasco, L., 2014.

Fired clay bricks manufactured by adding wastes as sustainable construction material - a review. Constr. Build. Mater. 63, 97-107.

NF EN 14 908, 2010. Solid Biofuels - Determination of Calorific Value.

Onésippe, C., Passe-Coutrin, N., Toro, F., Delvasto, S., Bilba, K., Arsène, M.-A., 2010. Sugar cane bagasse fibres reinforced cement composites: thermal considerations. Compos. Part Appl. Sci. Manuf. 41, 549-556.

Pasangulapati, V., Ramachandriya, K.D., Kumar, A., Wilkins, M.R., Jones, C.L., Huhnke, R.L., 2012. Effects of cellulose, hemicellulose and lignin on thermochemical conversion characteristics of the selected biomass. Bioresour. Technol. 114, 663-669.

Peters, T., Iberg, R., 1978. Mineralogical changes during firing of calcium-rich brick clays. Am. Ceram. Soc. Buelletin 503-505.

Quijorna, N., Coz, A., Andres, A., Cheeseman, C., 2012. Recycling of Waelz slag and waste foundry sand in red clay bricks. Resour. Conserv. Recycl. 65, 1-10.

Raut, S.P., Ralegaonkar, R.V., Mandavgane, S.A., 2011. Development of sustainable construction material using industrial and agricultural solid waste: a review of wastecreate bricks. Constr. Build. Mater. 25, 4037-4042.

Robert, S., Boynton, 1980. Chemistry and Technology of Lime and Limestone.

Shen, D.K., Gu, S., 2009. The mechanism for thermal decomposition of cellulose and its main products. Bioresour. Technol. 100, 6496-6504.

Stenseng, M., Jensen, A., Dam-Johansen, K., 2001. Investigation of biomass pyrolysis by thermogravimetric analysis and differential scanning calorimetry. J. Anal. Appl. Pyrolysis 58, 765-780.

Sutcu, M., Akkurt, S., 2009. The use of recycled paper processing residues in making porous brick with reduced thermal conductivity. Ceram. Int. 35, 2625-2631.

Toledo, R., Dossantos, D., Fariajr, R., Carrio, J., Auler, L., Vargas, H., 2004. Gas release during clay firing and evolution of ceramic properties. Appl. Clay Sci. 27, 151-157.

Vassilev, S.V., Baxter, D., Andersen, L.K., Vassileva, C.G., 2013. An overview of the composition and application of biomass ash. Fuel 105, 19-39.

Wagh, A.S., Poeppel, R.B., Singh, J.P., 1991. Open pore description of mechanical properties of ceramics. J. Mater. Sci. 26, 3862-3868.

Yakub, I., Du, J., Soboyejo, W.O., 2012. Mechanical properties, modeling and design of porous clay ceramics. Mater. Sci. Eng. A 558, 21-29.

Yang, H., Yan, R., Chen, H., Lee, D.H., Zheng, C., 2007. Characteristics of hemicellulose, cellulose and lignin pyrolysis. Fuel 86, 1781-1788.

Zabalza Bribián, I., Valero Capilla, A., Aranda Usón, A., 2011. Life cycle assessment of building materials: comparative analysis of energy and environmental impacts and evaluation of the eco-efficiency improvement potential. Build. Environ. 46, 1133-1140. 